\title{
Implementing electric vehicles in public services: a case study research
}

\author{
João Reis \\ Department of Economics, Management, Industrial Engineering \\ and Tourism, GOVCOPP, \\ Aveiro University, \\ Campus Universitário de Santiago, \\ 3810-193, Aveiro, Portugal \\ Email: reis.joao@ua.pt
}

\begin{abstract}
In the last years, most European countries have developed strategies to implement the use of electric vehicles. This paper uses a qualitative case study research in the automotive industry to evaluate the efficiencies concerning the implementation of the first electric light truck produced for public services. The results indicate that electric light trucks in public services are more efficient, economically reliable and contribute to the reduction of carbon dioxide emissions. Moreover, the strategy of using these vehicles is suitable for nocturnal collection of urban waste, to the extent that it reduces the daily traffic and, at the same time, drastically reduces the noise caused by diesel engines during night hours, thus, improving the quality of life on residential areas. By investing on such strategy, European governments are giving a step further to accomplish the European Commission requirements, which is stimulated by the reduction of the carbon dioxide footprint.
\end{abstract}

Keywords: electric vehicles; electric light trucks; case study; renewable energies; carbon dioxide; efficiency; public services.

Reference to this paper should be made as follows: Reis, J. (2019) 'Implementing electric vehicles in public services: a case study research', Int. J. Electric and Hybrid Vehicles, Vol. 11, No. 3, pp.205-216.

Biographical notes: João Reis is an Assistant Professor of Service Management (Aveiro University), Operations Management (ISLA-Santarém) and Supply Chain Management (Portuguese Military Academy). He received a $\mathrm{PhD}$ in Management and Industrial Engineering from Aveiro University. During the last 10 years, he has been conducting extensive scientific research in the service industry. He is a research fellow at the research unit on Governance, Competitiveness and Public Policy (GOVCOPP) in the fields of service science, industrial engineering and operations management. During his free time, he frequently performs humanitarian aid in Africa, Asia and around the South-eastern Europe.

\section{Introduction}

Vehicles moved by renewable energies are urgently needed in Lisbon, Portugal, due to the requirements imposed by the European Commission to reduce the carbon dioxide 
emissions, but also to decrease the economic impact of regular activities, e.g., the collection of urban wastes. However, the implementation of electric vehicles is not straightforward, although electric vehicles are commercially available, they are still not welcomed by most users mainly because of battery limitations (Høyer, 2008). The high prices of electric vehicles (EVs) are attributed to their expensive green components, as the battery is typically the most expensive component, which almost takes up $30-40 \%$ of the entire production cost of these vehicles (Fu et al., 2018). Therefore, a study conducted by Delang and Cheng (2013) has revealed that citizens from China, one of the most developed economies, recognise the positive environmental, economic and social benefits that electric vehicles bring but the aforementioned citizens also prefer not to purchase these vehicles due to the high costs. According to several studies (Black, 2000; Delucchi and Lipman, 2001; Weinert et al., 2008) the price of electric cars is higher than the internal combustion engine vehicles (ICEVs), again due to the high cost of the batteries, large investment involved on the research and the small numbers of electric vehicles that are still produced. However, these limitations are not consensual. An example of this is the United States (USA), where Xie et al. (2018) claim that the promotion of these electric vehicles is considered an effective solution helping the country reducing its dependency on imported oil and also allows to improve its competitive position in the emerging era of the renewable energy market. The empirical evidence of such strategy is visible by the sales of Nissan Leaf and the plug-in hybrid Chevy Volt of General Motors, which were introduced in the US market (Fu et al., 2018).

The electric vehicles in public services are a relevant discussion theme, well-noticed by the increasing of sales and production, which has aroused the interest of the academic community. This interest is also verified by the increasing promotion of special issues on hot topics, such as, alternative fuel vehicles (AFVs) or electric vehicle batteries, in order to build and promote scientific breakthroughs. Some of these examples are from top tier journals, that have recently opened call for proposals: (1) the Journal of Transportation Research Part D, has opened recently a call for paper with the topic "Advances in Alternative Fuel Vehicles"; and/or the (2) the Journal of Energy Storage, with the special issue "Second Life of Electric Vehicle Batteries in Stationary Applications".

Currently, all major foreign manufacturers and suppliers have located themselves in China during the last few years, alongside a large number of Chinese automotive manufacturers, and are already focusing their sourcing in particular on global markets (Proff, 2012). However, some manufacturers are changing this tendency, as an international corporation, responsible for the commercialisation of electric vehicles i.e. full electric-powered light trucks, started the production at the original equipment manufacturer (OEM) in Portugal. Currently, the Portuguese OEM is producing electric light trucks called $e$ Truck, which will become relevant to the Portuguese economy, since that country is going to export these vehicles worldwide and allows to expand market shares despite the increasing Chinese competition. The corporation has recently started the project in six cities around the world, which are: Lisbon, London, Berlin, Amsterdam, New York and Tokyo. Lisbon municipality has acquired 10 units for public services purposes (e.g., collection of urban waste) before acquiring a larger volume of units. At this time, the $e$ Truck is a pre-series production vehicle, which is expected to achieve the full production and availability to the markets in 2019-2020 to embrace sustainable and reliable transport solutions. 
Motivated by the above, this study focuses on the urban waste collection in Lisbon, due to its exponential increase in tourism in the last years. Consequently, the municipality has been facing an accelerated growth of urban waste. By studying the pros and cons a question remains: Are the electric light-duty trucks a reliable alternative to public services?

This paper is structured as follows: first, the author has reviewed the literature by presenting the state of the art; second, the author describes the methodological approach; third, it discusses the results regarding the studied real-life phenomenon; finally, it provides conclusions, implications and suggestions for future research.

\section{Literature review}

This section addresses the theoretical background, which the author considers essential to understand the phenomenon.

\subsection{The scope of electric vehicles}

In the West, the ambiguous term electric vehicles (EVs) is commonly used and mostly associated with battery EVs (BEVs) (Chen and Midler, 2016). The EVs are classified into three major categories by their fuel consumption technology: hybrid electric vehicles (HEVs), plug-in hybrid electric vehicles (PHEVs) and battery electric vehicles (BEVs), while both PHEVs and BEVs are also referred to as plug-in electric vehicles (PEVs), since they are designed to be recharged by plugging into the power grid (Zhu et al., 2018). Hence, Hybrids (HEVs) are vehicles with an electric drive system and an internal combustion engine running on either petrol or diesel (Milowski et al., 2018), while PHEVs are vehicles equipped with at least two energy sources to propel them (Xu et al., 2018), usually by combining electric and conventional propulsion (Plötz et al., 2018) and BEVs are considered vehicles that operate on batteries that have a limited life as well as specific charging and discharging patterns (Pelletier et al., 2017). In short, the new generation electric vehicles (EVs) are likely to become increasingly popular for city travellers and are expected to feature prominently in 'Smart Cities' of the future (Milowski et al., 2018). Although there are other conceptualisations, Mahmoudi et al. (2014) corroborates the earlier definitions and argues in favour of a broader classification, accordingly the degree of electrification (Figure 1).

Figure 1 Degree of electrification

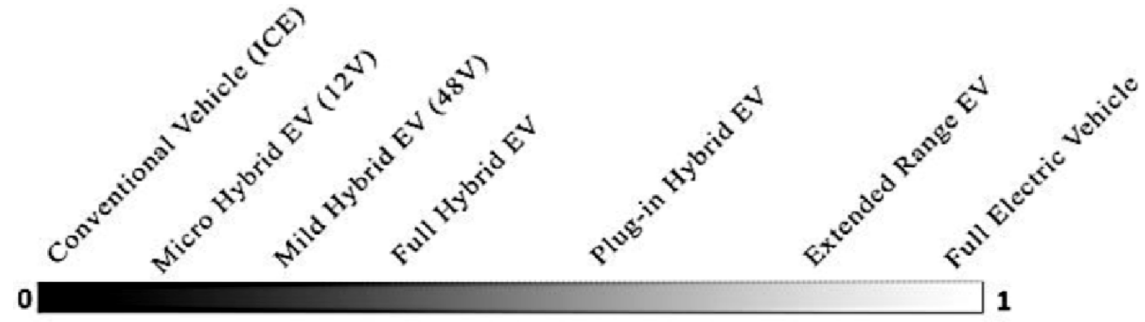

Source: Mahmoudi et al. (2014) 
Mahmoudi et al. (2014) defines each degree as:

- $\mathrm{BEV}$, uses high capacity batteries and electric motor for propulsion

- HEV uses mechanically a combination of electric motor (EM) in low speeds dedicated for in-city traffic and a conventional internal combustion engine (ICE) for use outside urban areas

- REEV are range extended electric vehicles, which are vehicles in which the propulsion is driven only by an electric motor powered by high capacity batteries

- FCEV (fuel cell electric vehicle) introduced to perform long distances because it uses a fuel cell system to power its on-board electric motor

- SEV are solar electric vehicles, which are directly or complementarily powered by direct solar energy.

Similar to other research papers (e.g., Chen and Midler, 2016), the author of this paper ended up on focusing on the EVs, namely the BEVs. He did not consider other fuel sources, such as the fuel cell EVs (FCEVs), due to the low maturity of this technology and its demanding supporting infrastructure in terms of cost, when compared with BEVs. According to Bansal (2005), the EVs have a much longer history than most people realise, since this technology was mentioned soon after Joseph Henry introduced the first DC-powered motor in 1830 and the first known first electric car was a small model built by Professor Stratingh in the Dutch town of Groningen in 1935 (Bansal, 2005). Bansal (2005) also states that, the first EV was built by in 1834 by Thomas Davenport in the USA, but there were no rechargeable electric cells batteries at that time, the EV did not become a viable option until the Frenchmen Gaston Plante and Camile Faure respectively invented and improved the storage battery.

\subsection{The strategic implementation of electric vehicles}

In the last years the urban transport has raised specific issues and brought attention to political, social and environmental prejudice of pollution, noise and stress (Racicovschi et al., 2007; Schiffer and Walther, 2018). Racicovschi et al. (2007) stressed that, the European Union (EU) is encouraging scientific and technological research activities to develop clean and efficient transport, mainly by incorporating limits to greenhouse effect with efficient solutions as the EVs. In addition, some EU countries are encouraging a sustainable market for EVs, by combining high taxes on high emissions and zero tax for zero emissions vehicles (ZEVs). Due to this practice, Norway has the highest number of electric vehicles per capita in the world by achieving in January 40,000 electric vehicles in a country of 5 million inhabitants (Haugneland and Hauge, 2015).

Although emissions do result from fossil fuelled generation of electricity, these emissions are removed in both space and time from the point of operation of a EV (Santini, 2011). In Portugal, the Portuguese Association of Renewable Energies (APREN) argue that, from January to August 2018, renewable energy sources have played a leading role in the electricity production, contributing with $55.3 \%$ to the total electricity generated (37,451 Gigawatt hours).

The results from Figure 2 are mainly driven by the availability of renewable resources, such as aeolian and hydraulic energy. Although the coal $(18.62 \%)$ and natural gas $(17.72 \%)$ are still relevant, to our best understanding, the overall result is still 
positive, since the production of renewable energy surpasses half of the national production of energy.

Figure 2 Renewable and fossil energy sources (see online version for colours)

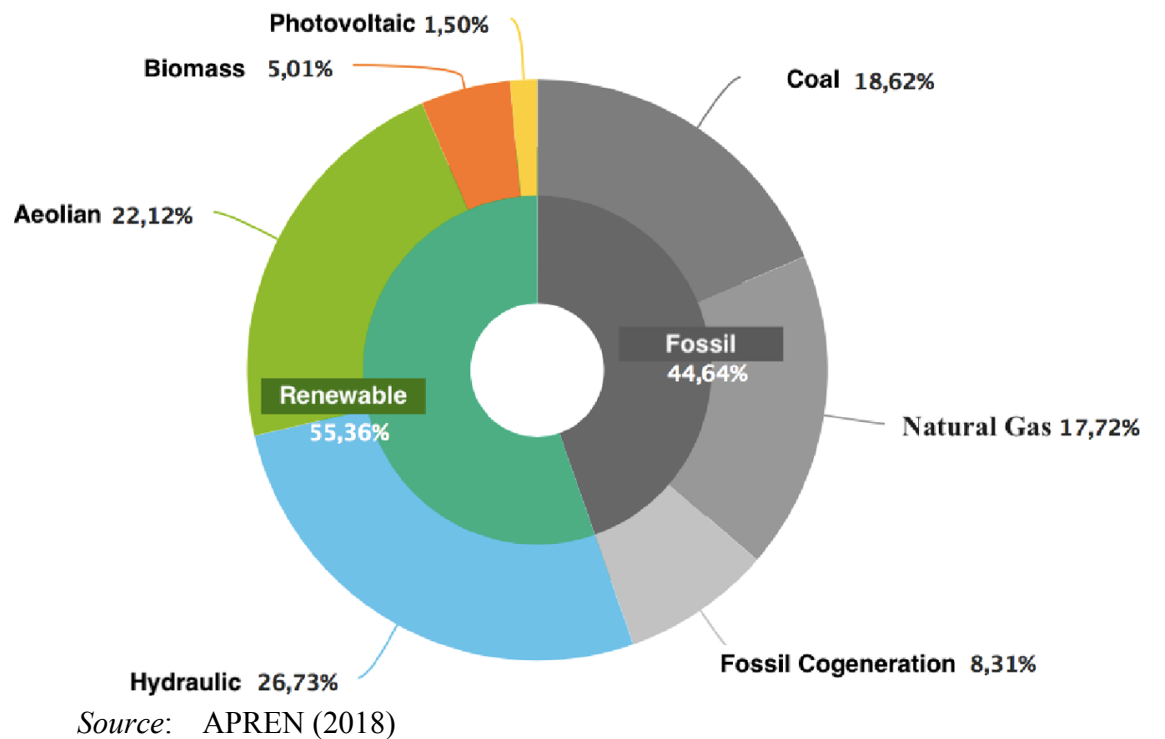

\subsection{European regulation for carbon dioxide emissions $\left(\mathrm{CO}_{2}\right)$}

Cities consume over two-thirds of the world's energy and account for more than $70 \%$ of global $\mathrm{CO}_{2}$ emissions (Kuppusamy et al., 2017). A salient characteristic of EVs is their cleaner environmental impacts relative to conventional fuel vehicles, as they have either zero or much less tailpipe greenhouse gas $(\mathrm{GHG}) / \mathrm{CO}_{2}$ emissions than conventional cars (Manjunath and Gross, 2017). As EVs have no combustion engine, there are no oil changes, tune-ups, or timing and there is no exhaustion (Bansal, 2005). The EU legislation sets mandatory emission reduction targets for new vehicles. According to the European Commission, cars are responsible for around $12 \%$ of total EU emissions of $\mathrm{CO}_{2}$, the main greenhouse gas, as 2021 targets represents a reduction of $40 \%$ compared with the 2007 fleet average of 158.7 grams of $\mathrm{CO}_{2}$ per kilometre (COM, 2014). On 8 November 2017, the European Commission presented a legislative proposal setting new $\mathrm{CO}_{2}$ emission standards for passenger cars and light commercial vehicles in the EU for the period after 2020, the proposal also includes a mechanism to incentivise the up-take of zero- and low-emission vehicles, in a technology-neutral way (COM, 2017). The objective of this proposal will contribute to the achievement of the EU's commitments under the Paris agreement. According to the European Commission the $\mathrm{CO}_{2}$ greenhouse gas most commonly produced by human activities is responsible for $64 \%$ of man-made global warming, a part of the causes for rising emissions are due burning coal, oil and gas which produces carbon dioxide and nitrous oxide (EC, 2018). The prospect of reducing $\mathrm{CO}_{2}$ emissions has also raised the obligation of European governments to embark on substantial programs to achieve a cleaner mobility. In particular, the Portuguese government is following that trend, by investing on 
upstream renewable energy sources that allows recharging of existing public service electric vehicles downstream.

\section{Methodology}

This paper reports on the results of a case study carried out in a Portuguese OEM. The objective was to understand the pros and cons of the implementation of electric vehicles to achieve clean practices of waste collection. This case study research uses multiple sources of data collation for triangulation purposes. The sources of data collection consisted of semi-structured interviews, direct observation and documental analysis. The author decided about using multiple sources of data collection as a form of triangulation to prevent exclusive reliance on a single data collection method and thus, aid to neutralise any bias inherent to a particular data source (Given, 2008).

The study builds on 11 semi-structured interviews conducted with employees from the OEM that is operating in Portugal and seven semi-structured interviews with the drivers of the $e$ Trucks. The researcher made use of his personal contacts network to identify the respondents who were best positioned to provide answers to the interview protocol. Convenient and snowball sampling was also used to select the respondents, as well as the recommendations and directions from the respondents of the first round of interviews. Prior to the interviews, the author obtained the participants' consent, which included the consent for audio recording. The direct observation involved observations to enable a better understanding about the real life phenomenon, thus, these observations were recorded in a research diary, that had notes from random visits to the sites and informal discussions about the company strategy and the successful of such implementation. The institutional documents were generally produced by the company for communication or record-keeping purposes and were sources of exceptional data collection (Mills et al., 2010), because most of the records were available at the official website.

The data analysis was examined according to the technique of content analysis, which is frequently recommended by scholars when the case research is qualitative by nature (Mills et al., 2010). The author categorised the transcript into codes and categories in order to identify patterns and relations between variables with the help of a qualitative data analysis software (NVivo11). The reliability and validity of the case study was achieved by a well-designed interview protocol and improved by double-checking the transcripts with the participants in order to avoid misinterpretations.

\section{Results and discussion}

This section provides an empirical summary of the case study research, presenting the pros and cons of implementing electric light trucks in European capitals for an effective public service with reduced $\mathrm{CO}_{2}$ footprint.

\subsection{Environmentally friendly policy}

As an EV, the $e$ Truck reduces the impact of exhaust and noise emissions on city centres, while it is also environmentally attractive when compared to diesel engines. 
The environmental impact has been widely discussed in the academic literature, but no consensus has been reached yet. The papers of Zivin et al. (2014) and Yuksel and Michalek (2015) describe the impact of temperature on EVs' efficiency, range and emissions, while McLaren et al. (2016) considers different charging scenarios and travel profiles of EVs and analyses their impact on the associated carbon emissions. However, there are a lot of questions that still remain open and one of them is "what happens at the end of the lifecycle of a battery and an electric motor?", as the number of sold electric vehicles will increase the amount of electric motors and battery waste will increase too, leading to a greater impact on the environment (Racz et al., 2015).

On the other hand, current research shows that EVs may have a role in reducing air pollution and its consequences for health. The study "How clean are electric vehicles? Review of the environmental and health effects of electric mobility" conducted by Requia et al. (2018) provides a comprehensive review of the effects of EV adoption on air quality, greenhouse gas emissions, and human health. Requia et al. (2018) have resumed relevant published papers, from up to 4734 studies, mostly carried out in the USA and China, out of which 65 papers fulfilled the inclusion criteria, showed consistently reductions in greenhouse gas emissions and emissions of some criteria pollutants. The respondents of our case study also emphasised the eco-friendliness of the $e$ Truck, which is expected to become one of the most important criteria to the Portuguese public administration acquisitions. The efficiency of electric light trucks fleet allows the possibility to balance the electricity usages rates and the electricity demand, since some of these vehicles are operating during the night hours. Moreover, the Portuguese government provides dedicated infrastructures of easy access to fast charging that reduces the $e$ Truck downtime.

\subsection{Economically reliable alternative to diesel engines}

Frequently, the fuel used by electric trucks is cheaper, when compared with ICEVs (Delang and Cheng, 2013). However, it is dependent on the weather conditions and low temperatures $\left(0^{\circ} \mathrm{C}\right.$ or below), which can have negative impacts on the battery's performance. This creates ineffectiveness and increases on-road energy consumption, which further limits the vehicle's range (Kim et al., 2008). Due to the temperate climate of Portugal, the aforementioned limitations are not observed, and do not have a real impact on the use of electric vehicles.

The limitations of Lisbon are quite the same as other cities around the world (e.g., Hong Kong), due to its compact and dense streets, most of trips are short in distance; therefore, the short range of electric vehicles (mostly within the 100-200 km range) would not represent a problem to the needs of public services (Delang and Cheng, 2013). Consequently, electric light vehicles might be a reliable choice, since the other forms of EVs (e.g., hybrid electric vehicles), as motor vehicles, are more credible to long distances (Racicovschi et al., 2007).

The $e$ Truck has a range of 100 kilometres and load capacity up to three and a half tons. This light-duty truck contains up to six high voltage lithium ion batteries of $13.8 \mathrm{kWh}$ each. According to the respondents, the batteries are charged with regenerative braking and deceleration which reduces the battery consumption. In addition, reports and direct observation have showed that, in comparison to diesel engines, the Portuguese public administration will have $30 \%$ lower maintenance costs and potential fuel savings of 1000 euros per $10,000 \mathrm{~km}$ (estimated values). 
The cons the author has recorded are associated to acquisitions costs because of the low production, since the $e$ Truck is still being in pre-test. On the other hand, for the most sceptical respondents, the autonomy of these vehicles can always be optimised with the research and development (R\&D) of more efficient batteries and green technologies. These findings are in line with the literature, as scholars argue that the relatively high costs of purchase and low durability of key components (e.g., batteries) are significant barriers to the wider use of electric vehicles (Delucchi and Lipman, 2001; Schiffer and Walther, 2018). Besides major environmental advantages, the EVs have not yet managed to penetrate massively into the car market and convinced possible users (Racicovschi et al., 2007), despite the limitations the Portuguese government is trying to push and accelerating the adoption of AFVs as ecological alternatives.

\subsection{Improving the quality of life in capital cities}

To improve the quality of life in Lisbon, the $e$ Truck is identified by the respondents as the most suitable vehicle to collect urban residues. The $e$ Truck mainly works during night hours and it can quietly travel the city without disturbing the local inhabitants. Despite the mentioned advantage, the respondents had also identified some constraints:

- The $e$ Truck cargo boxes are traditionally made of metal, and are the same as the combustion trucks, which are not zero-noise efficient; therefore, unless these boxes are adapted to keep a silent propulsion, the EV zero-noise advantage will be lost or reduced.

- The $e$ Truck also requires an independent front suspension to improve the driving quality, as well as a greater cushioning in the cabin. The $e$ Truck drivers stated the manufacturer should take into account that the city of Lisbon has many areas where the road surface is in poor condition, and this affects the driver experience. While this truck is in pre-test and before going to production on large scale, these limitations should be taken in consideration.

- Studies also refer that drivers of EVs experience range anxiety or worry about the limited driving range of these vehicles (Eberle and Von Helmolt, 2010). To avoid the driver range anxiety, the instrument panel of the $e$ Truck only shows the percentage of charging of the batteries, whether if the drivers need to know how many kilometres are left, they have to access the central screen and select the vehicle information.

Besides the zero-noise, the issue of poor air quality is also a pressing problem in many urban areas as it directly affects the health of people and as a result the life expectancy of citizens (Quak et al., 2015). At long term, despite the mentioned constraints, the respondents agreed the electric light trucks will definitely contribute to a reduction of the poor air quality that is felt in Lisbon area, and consequently will have a positive impact on the environment.

\subsection{Pros and cons of implementing electric light trucks at public services}

This section addresses the motivations which are driving the implementation of electric light trucks at public services. Table 1 identifies the pros and cons, and discusses possible solutions to constraints that were scholarly or empirically identified. 
Table 1 Pros and cons of light-duty trucks in public services

\begin{tabular}{|c|c|c|}
\hline \multirow[b]{2}{*}{ Pros } & \multicolumn{2}{|l|}{ Cons } \\
\hline & Drivers of EV adoption & Possible solution(s) \\
\hline $\begin{array}{l}\text { The instrument panel of the } e \text { Truck } \\
\text { only shows the percentage of } \\
\text { charging of the batteries. }\end{array}$ & \multicolumn{2}{|l|}{$\begin{array}{l}\text { Anxiety or worry about the } \\
\text { limited driving range of EV } \\
\text { (Eberle and Von Helmolt, } \\
\text { 2010). }\end{array}$} \\
\hline $\begin{array}{l}\text { The } e \text { Truck batteries are charged } \\
\text { with regenerative braking and } \\
\text { deceleration which reduces the } \\
\text { consumption. }\end{array}$ & $\begin{array}{l}\text { The EVs are substantially } \\
\text { more expensive than } \\
\text { combustion vehicles } \\
\text { (Delucchi and Lipman, 2001; } \\
\text { Schiffer and Walther, 2018). }\end{array}$ & $\begin{array}{l}\text { Decrease on-road energy } \\
\text { consumption and improve } \\
\text { effectiveness by increasing } \\
\text { the batteries' performance } \\
\text { and R\&D. }\end{array}$ \\
\hline $\begin{array}{l}\text { Positive environmental, economic } \\
\text { and social benefits that electric } \\
\text { vehicles bring: zero-emissions, } \\
\text { cost-efficient and zero-noise. }\end{array}$ & $\begin{array}{l}\mathrm{CO}_{2} \text { emissions may occur } \\
\text { upstream during the } \\
\text { production of energy from } \\
\text { fossil sources. }\end{array}$ & $\begin{array}{l}\text { Increase investment in } \\
\text { upstream renewable energy } \\
\text { sources and use of clean } \\
\text { downstream mobility. }\end{array}$ \\
\hline \multirow{2}{*}{$\begin{array}{l}\text { The } e \text { Truck is used to short } \\
\text { distances. The autonomy of } \\
\text { these vehicles will always be } \\
\text { optimised due to the technological } \\
\text { advancement of batteries over time. } \\
\text { Moreover, the } e \text { Truck have } \\
\text { dedicated infrastructures that } \\
\text { allows easy access to fast charging } \\
\text { that reduces the EV downtime. }\end{array}$} & \multirow[t]{2}{*}{$\begin{array}{l}\text { The EVs autonomy on road } \\
\text { is very limited. The EVs } \\
\text { derive short distances and } \\
\text { they have a longer charging } \\
\text { time than fuel combustion } \\
\text { vehicles (Fu et al., 2018). }\end{array}$} & $\begin{array}{l}\text { The weather conditions } \\
\text { and moderate temperatures } \\
\text { in-country has a positive } \\
\text { impact on energy } \\
\text { consumption. }\end{array}$ \\
\hline & & $\begin{array}{l}\text { Also, the advancements in } \\
\text { technology may reduce the } \\
\text { purchase prices, the charging } \\
\text { time and it may shorten the } \\
\text { lifetime of batteries. }\end{array}$ \\
\hline $\begin{array}{l}\text { The } e \text { Truck is most suitable to } \\
\text { reduce the noise impact on the city } \\
\text { centres, improving the quality of } \\
\text { life of its inhabitants. }\end{array}$ & $\begin{array}{l}\text { There are some other factors } \\
\text { that are neglecting the noise } \\
\text { reduction. E.g., cargo boxes } \\
\text { are very noisy. }\end{array}$ & $\begin{array}{l}\text { Optimisation of the } \\
\text { zero-noise driver. }\end{array}$ \\
\hline
\end{tabular}

The novelty of these results brings back solutions to old EVs' problems, which is the same to say that the $e$ Truck already integrates solutions that addresses issues previously raised in the literature. One of the most relevant finds is related to the improvement of the quality of life, either by improving the breathable air quality or by the releasing of zero-noise emissions. On the other hand, the introduction of EVs improves the Portuguese public administration, since the EVs are cost-efficienct, but it might also incentivise private markets to follow the same ecological practices. However, the author of this paper has doubts regarding the governmental support for the private practices, as better strategies and implementation plans might be needed, similarly to a study conducted in the UK, that revealed ineffectual strategies regarding the EV uptake and infrastructure provision (Heidrich et al., 2017).

Briefly, the paper shows that the implementation of electric light trucks is suitable to improve the efficiency of public services, although there are still some gaps listed in this paper that needed to be solved, among others that were not investigated. 


\section{Conclusions}

The Portuguese government has implemented a comprehensive strategy to push the use of zero-emissions vehicles in some public services. The results suggest that electric light trucks are cost-efficient, zero-noise and eco-friendly (zero-emissions). This study has both theoretical and managerial insights, as we look at the emergence of dominant electric trucks on public services and we provide the most relevant pros and cons of such implementation.

As this study is suitable to build a better understanding of a real-life phenomenon, it also points out some limitations: The ' $e$ Truck' term is fictitious, since the author decided not to explicitly reveal the identity of the manufacturer and the respective participants. The reason that led us to undertake an agreement of confidentiality is due the respondents' reluctance to discuss the disadvantages of the $e$ Truck. A limitation that was mitigated with direct observations and documental analysis, which corroborated the results the author has found from the formal interviews. In the same vein, this case study research does not allow generalisation; however, the author believes the ongoing projects at the aforementioned capital cities might provide some additional and relevant contributions.

The author also suggests avenues for further research, as it would be interesting to carry out a similar study in other countries for corroboration purposes. Thus, an important research area is the development of a better understanding of the topic, since this research is limited to its exploratory nature. Besides yielding a better understanding about the state-of-the-art of new automobile trends, this paper aims at helping guide future policy and planning towards the introduction of electric vehicles in public services.

\section{References}

APREN (2018) Balanço da produção de eletricidade de Portugal continental (janeiro a agosto de 2018), http://www.apren.pt/pt/energias-renovaveis/producao (Accessed 23 September, 2018).

Bansal, R. (2005) 'Electric vehicles', Electrical and Computer Engineering, Vol. 125, No. 55, pp.1-43.

Black, W. (2000) 'Socio-economic barriers to sustainable transport', Journal of Transport Geography, Vol. 8, No. 2, pp.141-147.

Chen, B. and Midler, C. (2016) 'The electric vehicle landscape in China: between institutional and market forces', International Journal of Automotive Technology and Management, Vol. 16, No. 3, pp.248-273.

COM (2014) Regulation (EU) No 333/2014 of the European Parliament and of the council of 11 March 2014 to Define the Modalities for reaching the 2020 Target to Reduce $\mathrm{CO}_{2}$ Emissions from New Passenger Cars, European Commission Report.

COM (2017) Proposal for a Regulation of EP and the Council Setting Emission Performance Standards for New Passenger Cars and for New Light Commercial Vehicles as Part of the Union's Integrated Approach to Reduce $\mathrm{CO}_{2}$ Emissions from Light-Duty Vehicles and Amending Regulation (EC) No 715/2017, European Commission Report.

Delang, C. and Cheng, W-T. (2013) 'Hong Kong people's attitudes towards electric cars', International Journal of Electric and Hybrid Vehicles, Vol. 5, No. 1, pp.15-27.

Delucchi, M. and Lipman, T. (2001) 'An analysis of the retail and lifecycle cost of battery-powered electric vehicles', Transportation Research Part D: Transport and Environment, Vol. 6, No. 6, pp.371-404. 
Eberle, U. and Von Helmolt, R. (2010) 'Sustainable transportation based on electric vehicle concepts: a brief overview', Energy \& Environmental Science, Vol. 3, No. 6, pp.689-699.

EC (2018) Causes of Climate Change, European Commission, https://ec.europa.eu/clima/change/ causes_en (Accessed 23 September, 2018).

Fu, J., Chen, X. and Hu, Q. (2018) 'Subsidizing strategies in a sustainable supply chain', Journal of the Operational Research Society, Vol. 69, No. 2, pp.283-295.

Given, L. (2008) The SAGE Encyclopedia of Qualitative Research Methods, Sage Publications, Thousand Oaks, California.

Haugneland, P. and Hauge, E. (2015) 'Norwegian electric car user experiences 2014', World Electric Vehicle Journal, Vol. 7, pp.1-9.

Heidrich, O., Hill, G., Neaimeh, M., Huebner, Y., Blythe, P. and Dawson, R. (2017) 'How do cities support electric vehicles and what difference does it make?', Technological Forecasting and Social Change, Vol. 123, pp.17-23.

Høyer, K. (2008) 'The history of alternative fuels in transportation: the case of electric and hybrid cars', Utilities Policy, Vol. 16, No. 2, pp.63-71.

Kim, B., Tredeau, F. and Salameh, Z. (2008) 'Performance evaluation of lithium polymer batteries for use in electric vehicles', Paper presented at the Vehicle Power and Propulsion Conference, 3-5 September, Harbin, China, pp.1-5.

Kuppusamy, S., Magazine, M. and Rao, U. (2017) 'Electric vehicle adoption decisions in a fleet environment', European Journal of Operational Research, Vol. 262, No. 1, pp.123-135.

Mahmoudi, C., Flah, A. and Sbita, L. (2014) 'An overview of electric Vehicle concept and power management strategies', Cell, Vol. 216, No. 50, pp.911-920.

Manjunath, A. and Gross, G. (2017) 'Towards a meaningful metric for the quantification of GHG emissions of electric vehicles (EVs)', Energy Policy, Vol. 102, pp.423-429.

McLaren, J., Miller, J., O'Shaughnessy, E., Wood, E. and Shapiro, E. (2016) ' $\mathrm{CO}_{2}$ emissions associated with electric vehicle charging: the impact of electricity generation mix, charging infrastructure availability and vehicle type', The Electricity Journal, Vol. 29, No. 5, pp.72-88.

Mills, A., Durepos, G. and Wiebe, E. (2010) Encyclopedia of Case Study Research, Sage Publications, California.

Milowski, J., Bhattacharjee, K., Singh, H. and Ray, T. (2018) 'Alternative passenger cars for the Australian market: a cost-benefit analysis', Data and Decision Sciences in Action, Springer, Cham., pp.163-173.

Pelletier, S., Jabali, O., Laporte, G. and Veneroni, M. (2017) 'Battery degradation and behaviour for electric vehicles: review and numerical analyses of several models', Transportation Research Part B, Vol. 103, pp.158-187.

Plötz, P., Funke, S. and Jochem, P. (2018) 'Empirical fuel consumption and $\mathrm{CO}_{2}$ emissions of plug-in hybrid electric vehicles', Journal of Industrial Ecology, Vol. 22, No. 4, pp.773-784.

Proff, H. (2012) 'Managing the transition to electric mobility in Chinese automotive subsidiaries of MNCs', International Journal of Automotive Technology and Management, Vol. 12, No. 4, pp.330-344.

Quak, H., Nesterova, N. and Rooijen, T. (2015) 'Possibilities and barriers for using electric-powered vehicles in city logistics practice', Transportation Research Procedia, Vol. 12, pp.157-169.

Racicovschi, V., Chefneux, M. and Danciu, G. (2007) 'Romanian concerns in the field of electric vehicles', International Journal of Electric and Hybrid Vehicles, Vol. 1, No. 1, pp.46-56.

Racz, A., Muntean, I. and Stan, S. (2015) 'A look into electric/hybrid cars from an ecological perspective', Procedia Technology, Vol. 19, pp.438-443.

Requia, W., Mohamed, M., Higgins, C., Arain, A. and Ferguson, M. (2018) 'How clean are electric vehicles? Evidence based review of the effects of electric mobility on air pollutants greenhouse gas emissions and human health', Atmospheric Environment, Vol. 187, pp.64-77. 
Santini, D. (2011) 'Electric vehicle waves of history: lessons learned about market deployment of electric vehicles', Electric Vehicles-The Benefits and Barriers, IntechOpen, pp.35-62, Retrived from: http://cdn.intechopen.com/pdfs/18663/InTech-Electric_vehicle_waves_of _history_lessons_learned_about_market_deployment_of_electric_vehicles.pdf

Schiffer, M. and Walther, G. (2018) 'Strategic planning of electric logistics fleet networks: a robust location-routing approach', Omega, Vol. 80, pp.31-42.

Weinert, J., Ogden, J., Sperling, D. and Burke, A. (2008) 'The future of electric two-wheelers and electric vehicles in China', Energy Policy, Vol. 36, No. 7, pp.2544-2555.

Xie, F., Liu, C., Li, S., Lin, Z. and Huang, Y. (2018) 'Long-term strategic planning of inter-city fast charging infrastructure for battery electric vehicles', Transportation Research Part E: Logistics and Transportation Review, Vol. 109, pp.261-276.

$\mathrm{Xu}, \mathrm{F}$., Jiao, X., Wang, Y. and Jing, Y. (2018) 'Battery-lifetime-conscious energy management strategy based on SP-SDP for commuter plug-in hybrid electric vehicles', IEEJ Transactions on Electrical and Electronic Engineering, Vol. 13, No. 3, pp.472-479.

Yuksel, T. and Michalek, J. (2015) 'Effects of regional temperature on electric vehicle efficiency, range, and emissions in the United States', Environmental science \& technology, Vol. 49, No. 6, pp.3974-3980.

Zhu, Z., Gao, Z., Zheng, J. and Du, H. (2018) 'Charging station planning for plug-in electric vehicles', Journal of Systems Science and Systems Engineering, Vol. 27, No. 1, pp.24-45.

Zivin, J., Kotchen, M. and Mansur, E. (2014) 'Spatial and temporal heterogeneity of marginal emissions: implications for electric cars and other electricity-shifting policies', Journal of Economic Behavior \& Organization, Vol. 107, pp.248-268. 